\title{
Like chameleons. Civil servants and corruption in Malawi
}

Gerhard Anders

\section{(e) OpenEdition \\ Journals}

Electronic version

URL: http://journals.openedition.org/apad/137

DOI: 10.4000/apad.137

ISSN: 1950-6929

Publisher

LIT Verlag

\section{Printed version}

Date of publication: 1 December 2002

\section{Electronic reference}

Gerhard Anders, «Like chameleons. Civil servants and corruption in Malawi », Bulletin de l'APAD

[Online], 23-24 | 2002, Online since 15 December 2006, connection on 07 September 2020. URL : http://journals.openedition.org/apad/137 ; DOI : https://doi.org/10.4000/apad.137

This text was automatically generated on 7 September 2020

Bulletin de l'APAD 


\title{
Like chameleons. Civil servants and corruption in Malawi
}

\author{
Gerhard Anders
}

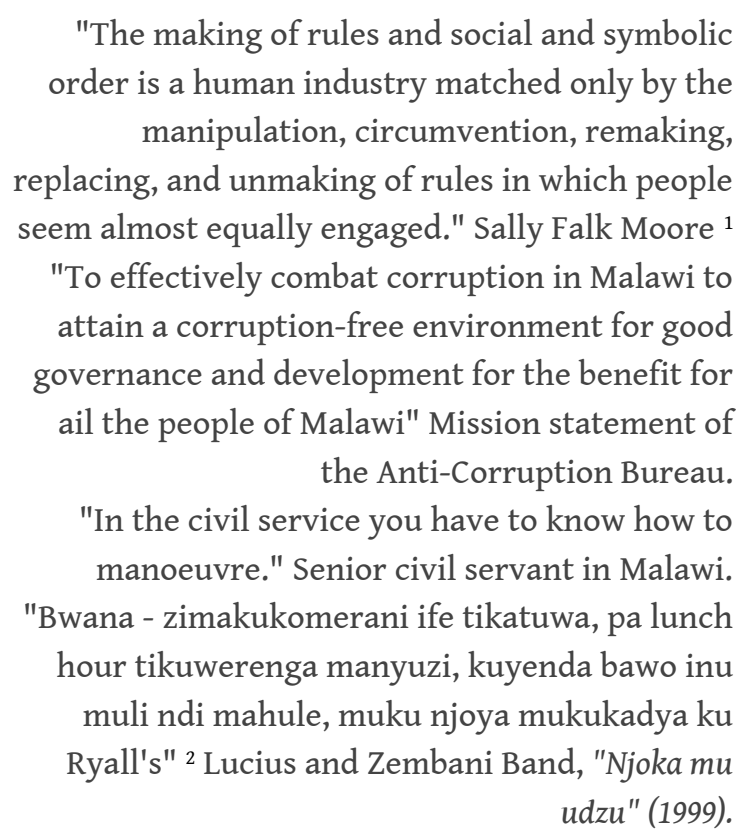

While doing fieldwork in Malawi in 1999 and $2000 \mathrm{I}$ often had to marvel at the apparent ease with which civil servants managed their widely branching networks; bridging huge differences in social position and location, negotiating virtuously a course between their own interests, the claims of spouses, children and kin and the public office. They seemed to be always on the move : between the office, the garden where they grew maize, private businesses, relatives coming to see them and they themselves visiting family in the home village, switching effortlessly between the different codes and signs of these networks and locations. They reminded me of chameleons, apparently slow, inscrutable, their eyes always in motion, scanning independently from each other in an directions, changing their colours according to the environment in order to make them invisible to their enemies, yet never losing sight of their aims. ${ }^{3}$ 
2 This paper deals with one particular aspect of civil servants' social lives that has received a lot of attention in recent years by the international donor community and social scientists alike : corruption. More by default than by design I came into touch with corruption, which has become a common phenomenon in the bureaucracy of Malawi and has a prominent place in public discourse. My scope was much wider : my research was primarily aimed at analysing civil servants' social networks and forms of support within this social networks. Hence, I hope that this problematic normative concept did not bias the analysis of my informants' behaviour. Often corruption is just one, often min or, aspect of civil servants' social lives. In my point of view it is important to make this very clear at the outset of my paper to avoid stereotypical representations of parasitic and corrupt African civil servants that skew the analysis of more complex social interactions.

3 In Malawi, as in most African countries, networks based on affectionate ties, for example kinship, are extensive and very strong. Relationships with others usually convey strong moral imperatives, a sense of obligation and entail certain expectations. In the context of a very small formal sector civil servants are special. They enjoy a regular salary, various benefits and have direct access to the state's resources. They have a privileged position in comparison to the overwhelming majority of the population eking out an existence by subsistence farming, piecework or small-scale business. Their privileged position makes them a prime target for relatives $100 \mathrm{king}$ for help, especially under the present adverse economic conditions in Malawi (Anders 2002a). Many of the civil servants have talked to have a strong sense of obligation and find it very difficult to refuse a request for help by a relative, even if doing so would entail the violation of office regulations. This is exacerbated by the intensity of social control: non-compliance with kinship obligations carries the threat of serious sanctions, such as ostracism and witchcraft, ufiti, while the chances of being charged with corruption are relatively slim. But it would be wrong to assume that civil servants are merely responding to the demands of an "uncaptured peasantry" (Hyden 1980). On the contrary, holding a public office gives them access to resources, which they can exploit as brokers ${ }^{4}$ also to their own advantage. The ambiguity and tension, which is created by the co-existence and conflict of different normative orders, is exploited by civil servants who cunningly adapt to their environment to maximise their profit and to protect or improve their position.

4 Therefore I would like to approach corruption from a different angle, not as deviant behaviour but rather embedded in a society where the modern division between the public office and the private is not the exclusive manner of defining a civil servant's place in social space. State law is only one of the multiple sets of rules operating within the civil service of Malawi. Social obligations based on affectionate affiliation like kinship or patron-client relationships have a strong influence on people's social lives. Within the civil service, clandestine rules and principles exist parallel to official rules and regulations. Civil servants are exposed to these various sets of rules and try to maintain their position in the civil service, the extended family and patronage networks with their conflicting claims and obligations. This co-existence and interaction of multiple sets of rules within the bureaucracy can best be described in terms of legal pluralism. To begin with I will discuss what the word corruption refers to and how it is used in Malawi. The perception of corruption in Malawi has been shaped by the political and socio-economic changes the country has been experiencing since 
its democratisation in the mid-1990s. The main part of the paper will deal with the connection between legal pluralism and corruption within the civil service of Malawi drawing on a case study of a senior civil servant negotiating the claims of the different sets of rules. The case study will serve as a point of reference for a more general analysis of the interplay of different sets of rules within the state bureaucracy, which draws on the concept of legal pluralism.

What is corruption in Malawi ?

The idea of a public office separate from an official's private affairs, the basis for the definition of corrupt behaviour, is a relatively recent concept firmly rooted in the Western political and philosophical tradition. Until the $19^{\text {th }}$ century it was common in Europe and its colonies to see the public office as private property. Many practices, which were perfectly legitimate in earlier times, would qualify today as corruption or patronage. The distinction between the public office and private affairs only gained hold in Europe during a long gradual process, which culminated with the advent of the Weberian model of bureaucracy (Scott 1979; Weber 1980/1921; Wertheim 1964). The argument of relativity does not only apply to comparisons across time but even today there exist considerable differences in regard to what qualifies as illegal corruption between different countries despite the globalised discourse on corruption and how to deal with it. In recent scholarly writing different definitions of the phenomenon have been suggested. ${ }^{5}$ Despite all differences most authors acknowledge a couple of common features. Virtually all definitions are centred on the misuse of the public office for private ends (Epko 1979: 3, Gardiner 2002). Authors who have recently written on corruption have largely abandoned the attempt to arrive at a detailed yet universal definition and use a pragmatic and broad definition instead. They simply define corruption as the misuse of the public office for private gains thus attaining a definition that is flexible and open enough to account for the specific circumstances of a situation (See e.g. Olivier de Sardan 1999, Harsch 1999). This broad definition covers a whole range of illegal and semi-legal practices: bribery, embezzlement, misappropriation, fraud, use of the public office to exert influence, "favours" for friends and relatives, etc. Under corruption in this broad sense fall also patronage and nepotism, either illegal or semi-legal, when they are connected to the public office.

In spite of this quite extensive definition two differentiations need extra attention: firstly, with respect to the nature of the exchange relationships and, secondly, with regard to the scale. Scott makes a distinction between market corruption and parochial corruption : the first is defined as an impersonal exchange of money between an official and those who can pay while the second denotes "a situation where only ties of kinship, affection, caste and so forth, determine access to the favours of power holders" (Scott 1979 : 43-45). This distinction is important since it draws attention to the existence of roles of kinship, friendship, etc, which are based on a different morality than state law. However, both forms of corruption often overlap considerably: even if one has the necessary money he still has to know who to bribe and how to do it "properly" and it is not uncommon that a service for a relative also has a pecuniary aspect.

Bayart points out that "contrary to the popular image of the innocent masses, corruption and predatoriness are not found exclusively amongst the powerful" (1993 : 238). Indeed, one of the common characteristics of corruption in Sub-Saharan Africa is that it is not restricted to a specific class or group of people. Blundo and olivier de Sardan have recently emphasized the importance of "la petite corruption quotidienne" 
for an understanding of the functioning of the state bureaucracy in an empirical study conducted in francophone West-Africa (2001a). Generally, grand corruption can be easily distinguished from petty corruption. Grand corruption is practised by presidents, ministers, Principal Secretaries and Secretaries and involves huge sums of money paid as kick-backs or "commissions". Petty corruption involves police officers at a road-block, the clerk or the messenger at the District Administration demanding an extra payment, store clerks selling stationery, school-masters selling exercise books and drivers using government vehicles for private business. Despite the obvious differences between grand and petty corruption in terms of scale and actors it makes sense to perceive of them as two extremes "on a continuum of forms of corruption" (Olivier de Sardan 1999 : 250).

8 Since 1994 corruption has become a hotly debated issue in Malawi and everybody including civil servants themselves can relate stories of the greed and inefficiency of public servants. The fight against corruption in Malawi in its present form is a phenomenon of the late 1990s and is linked to the country's transition to multi-party democracy. The new president, Bakili Muluzi, was elected in the first free elections in 1994 and re-elected in 1999. The new government and parliament took several anti-corruption measures, often under considerable donor pressure. In 1995 parliament passed the Corrupt Practices Act and in 1998 the donor-funded Anti-Corruption Bureau became operation al. This policy is a direct product of the promotion of "good governance" by the World Bank, the IMF and the international donor community (e.g. World Bank 2000a, 2000b). And indeed these efforts to fight corruption seem to be necessary. All informants I talked to, not only civil servants, stress that before 1994 corruption was virtually unknown in Malawi. People often express sentimental feelings for the "good old time" under Kamuzu Banda, Malawi's autocratic ruler between 1964 and 1994, when crime and corruption were rare exceptions and when people got their jobs in the government on grounds of their qualifications and not because of their connections to senior civil servants and politicians. Popular discourse draws a clear line between the period under Banda's rule with no corruption, on the one hand, and the time since 1994 under the democratically elected Bakili Muluzi with widespread corruption, on the other hand. In my view it is impossible to discharge of this discrepancy by the simple assertion that people always idealise a better past in contrast to a harsh present. The general firm consensus on this point requires clarification. But limited available space forces me to merely indicate contributing factors.

Firstly, corrupt behaviour has often become a matter of survival. Malawi has been in the grip of economic decline since 1982, which has turned into a full-blown economic crisis since the early 1990s, when free-market reforms were being implemented by the World Bank and the IMF. Inflation has constantly eroded civil servants' salaries : in 1992 the real value of basic salaries was about 50\% below the levels of 1982 (World Bank 1994 : 37-39). Due to currency devaluations and high inflation rate this trend has intensified since $1994^{6}$. Poverty is widespread, endemic illnesses such as HIV/AIDS and malaria produce staggering mortality rates and civil servants are not only confronted with their own social decline but also by more demands on their resources from impoverished relatives and friends. Furthermore there is growing discontent about the glaring income differences between them and functionaries of donor agencies and NGOs who do the same job and have the same qualifications but who earn several times 
the salary of a civil servant ${ }^{7}$. Consequently, civil servants often refer to their meagre salaries as a justification and explanation of corrupt behaviour.

Secondly, since the introduction of multi-party democracy, matipati, in 1994 the media and people talk more freely about corruption than in the past. Under Banda strict control and arbitrary arrests of "confusionists" and "separatists" created a culture of paralysis and fear. Now newspapers have more leeway to address corruption and people dare to talk more openly about misconduct of public officials. This is something unheard of under Banda's rule. Therefore I tentatively conclude that corrupt behaviour which might have occurred prior to democratisation was just not talked about in public or even in private.

11 Thirdly, the impact of donor funded programmes to promote human rights and "good governance" has influenced the shift in public perception and contributed to the more open discussion of corruption just mentioned. In the past practices perceived to be corrupt were considered just a part of the political system. In fact, there existed no boundaries between Kamuzu Banda's personal property, the ruling party MCP (Malawi Congress Party, the only legal party till 1994) and the state institutions. As a retired district commissioner put it : "when the district officer of the MCP wanted to borrow your tractor you couldn't refuse, could you ?" This has changed considerably since democratisation in 1994 and politicians and functionaries are often accused of corruption. As a matter of fact, politicians routinely accuse each other of corruption, corruption allegations have become part of political power struggles (Englund 2002). It is important to take these changes into account in order to avoid an ahistorical and therefore flawed analysis. A study that is sensitive of social and cultural peculiarities has to take the specific historical background into account. Especially, with regard to Malawi this is crucial since the country used to be considered to be one of the least corrupt countries in sub-Saharan Africa.

In everyday conversations people quite frequently use the English word but in a very broad sense, covering corruption in the legal sense of the term, i.e. bribery, and all kinds of illicit practices like fraud, theft, embezzlement, etc. In everyday conversations, newspaper reports, official documents and statements by politicians, practices denoted with the English word corruption are invariably condemned as something poisonous that has to be eradicated or stamped out. However, the general rejection of "Corruption" does not imply a clear and unequivocal rejection of practices considered to be corrupt among average Malawians if we investigate the vernacular. ${ }^{8}$

In many conversations people use the Chichewa word katangale. Katangale denotes any kind of illegal, dubious or shady de al or practice connected to the place of work or the office in the formal sector that serve the enrichment of the employee. Katangale also covers nepotism and patronage since the two practices will often be connected. When people refer to corruption by the English word they generally express their strong disapproval and rejection. On the other hand, when they refer to katangale they are more ambiguous. Although people do not approve of it they will often talk about it in a rather ironic fashion acknowledging the fact that it is an intrinsic aspect of formal employment. The meaning depends on the intonation. Katangale is not so much an individualist action but rather an aspect of "the system" or "the way of doing things". The perception is that katangale is not an act of a person's free will but rather something he or she is drawn into, it appears as something you do because "that is the 
way how things are done around here", a system that does not really leave you an alternative way of doing things.

Katangale has strong redistributive connotations and is linked to the notion of "sharing", kugawa or kugawira. If others benefit from katangale the corrupt behaviour is considered to be acceptable and morally right. If the perpetrator of katangale violates the obligation to share people who expected their share will find ways to take revenge or punish the wrongdoer. Moreover, katangale is characterized by its secrecy. In this sense the concept resonates with witchcraft, ufiti, which is also characterized by secrecy and perceived to be something that can be beyond human agency. If katangale is used in a negative non-redistributive way it is often linked to practices of ufiti. Katangale is clearly differentiated from theft, kuba. Theft is an individual action for one's own benefit. Kuba does not evoke the redistributive associations of katangale, kuba is always strongly rejected as wrongful act. Kuba is legally and morally wrong and it can be in no way justified. For example, in the markets it is common practice that a thief who is caught red-handed is subjected to spontaneous mob-justice that often results in the death of the thief. Aside from the unequivocal disapproval of theft this example also highlights another distinction : $k u b a$ is usually an open act, normally not associated with the supernatural or magical as katangale can be, especially if it is used in a negative sense. These observations regarding the concept of katangale indicate that the attitude towards the use of the public office for "private" ends is more complicated and multi-layered than the state legislation and regulations seem to suggest.

Corruption and legal pluralism

15 In order to understand the existence of corruption in Malawi it is necessary to address the co-existence of different sets of norms or legal pluralism within the bureaucracy. In other words, adherence to one set of norms may contribute to or entail violation of another one. Official rules prohibit bribery and corrupt practices but do not account for the extensive obligations towards kin, for example. In turn, kinship or patron-client relationships have no separate rules concerning the distinction between public and private; the civil servant is expected to grant access to all resources he controls or is thought to control to kith and kin. This discrepancy has contributed to the development of an informal clandestine set of rules among civil servants which is different from other rules such as official regulations and kinship obligations.

State law and civil service regulations co-exist with rules of kinship and other personal relationships. Most authors writing on the subject have acknowledged the existence of normative pluralism in regard to corruption in countries of the South. Olivier de Sardan, for example, points out that 'the functioning of the administrative apparatus, entirely copied from a European pattern, is schizophrenic in type. In law, official functioning and budget, it is totally occidental. In practice, it is otherwise, traversed by logics in drastic contradiction with the original model. Thus, what is considered to be corruption from the perspective of official norms is not, or seldom, viewed in the same light from the perspectives of practical norms and actual practices (1999: 263). This is the reason why in the civil service 'very widespread adherence to abstract official norms of European origin, which advocate the impartiality of the state and the necessity of an ethic of public interest, thus coexists peacefully with an equally prevalent pattern of behaviour in conformity with social norms that favour personal and partisan interests (ibid.). 

be analysed in terms of a contradiction between different sets of norms (Médard 1995, Olivier de Sardan $1999: 263$ ). State law is just one of many sets of rules within a social field or context, interacting and overlapping with customary law, religious law or other forms of informal rules. ${ }^{9} \mathrm{~A}$ social field is defined as a smaller unit within a complex society "with rule-making capacities, and the means to induce or coerce compliance." This field, however, is not completely independent from outside influences; it possesses only semi-autonomy. Thus external rules usually co-exist with the internal rules in a process of continuous change and interaction with each other (Moore 1973). To conceptualise the civil service as a semi-autonomous social field allows us to distinguish and to analyse the various sets of norms, which create a situation of legal pluralism in regard to corrupt behaviour of public officials.

Rules as such are abstract and do not interact themselves. Social actors, people, interact with each other and in doing so they use rules as a resource to define their position and to achieve their objectives (Galanter 1981). Civil servants are very adept in navigating their course through the normative plurality and the other social actors. They suffer and profit at the same time from conflicting norms. On the one hand, they often are caught in "catch-22 situations" since whatever they do will result in a violation of a rule: if you help your brother you might have to violate official regulations but if you do not help him you run the risk of undermining kinship solidarity. On the other hand, civil servants use this very position as a resource and as brokers, they will always make sure that they get their share, either by profiting themselves or improving their status and position in their respective networks.

\section{A Chameleon in Action}

19 As mentioned above corruption was not the focus of my research during fieldwork. I concentrated on forms of social support involving civil servants and the ways they combine and negotiate their roles as public officials and members of a family, a circle of friends, a neighbourhood, a church or a burial association. Obviously, in the course of exploring these issues I could not avoid this hot topic, which everybody, including civil servants themselves, associated with the civil service. However, it is extremely difficult to actually see acts of corruption and to establish their connection with obligations towards kin or patron-client relationships.

People are often not willing to talk about concrete cases of corruption, a lot of stories are hearsay, a white researcher arouses suspicion and everything is shrouded in secrecy and allusions. The researcher who informs directly about corruption will only get the general rumours he or she can also find in the papers but no details on interfaces with informal networks and the influence of social obligations.

21 For these reasons I do not agree completely with authors who want to study the state by addressing corruption. Of course, a thick description of corrupt practices will tell us a lot about the state, how it works and how it is perceived. But that is exactly the problem. It is very difficult to get a good view on corruption and the situations it occurs in since these practices are usually conducted in a sphere of secrecy and confidentiality. Instead I argue that any in-depth study on the social lives of public officials would tell us a good deal about both, the state and corruption. I came by chance to the most valuable information, often indirectly when talking about other issues. The information I eventually gathered resembles more a puzzle with many separate pieces, which eventually give a fairly good general picture but I have few cases 
where I could witness the whole complex of practices and conflicting rules that forms the context of corruption in Malawi. One of the most complete cases is described in the following. The name of the civil servant is fictive to protect his identity and I do not disclose place names, the department or any other information, which might reveal the identities of the people involved.

Mr. Mashanga was a senior civil servant. In his early forties he was at the height of his career, Administrative officer in the Superscale. It was amazing to see how he handled his superior officers, subordinates, relatives, clients and all kinds of relationships including that with a European PhD-student. Like a chameleon he switched effortlessly between codes and environments, talking a very learned and bookish English at one moment and within a split second putting a subordinate or client at ease with a funny remark in Chichewa. He had contacts everywhere, from the patrons of seedy bottle-stores in town to the highest officials in the civil service. He could arrange almost anything and his subordinates would react on the wink of a finger. Everywhere he was greeted with respect and although he did not belong to the highest echelons of power he could mobilise an impressive network and certainly had a high social status.

He lived in large house provided by the government. His wife, who had also been a civil servant, had passed away a year ago and he lived together with his son and a number of relatives and dependants, some of them in the main house, others in servants' quarters. Two of the younger ones attended school in town. Ail of them depended on him for accommodation, school fees, food and hoped to find employment through his contacts in the civil service. He had enjoyed a good education at a missionary boarding school and had graduated from the University of Malawi in 1985. His father had been a primary school teacher and had made quite an effort to ensure that his son would get a good education. Being a Chewa from Kasungu district in the Central region he had probably benefited from Banda's policy to pro vide better access to university education and employment in the civil service for the AChewa, his own ethnic group and power base ${ }^{10}$. Mr. Mashanga had joined the service in the late 1980 s as Administrative Officer, the entrance grade for people with a university degree. Later he had served on different posts where he distinguished himself as able administrator and a good leader who had both, the respect of his superior officers and the loyalty of his subordinates. Swiftly he moved up the promotional ladder to the post he had already held for a few years when I met him.

Mr. Mashanga employed a housekeeper who lived together with his wife, his children and his mother in one of the servants' quarters on Mr. Mashanga's compound. Although the housekeeper worked in the household and was paid wages it would be inadequate to describe their relationship only in terms of an employment contract. Their relationship resembled more a patron-client relationship between relatives. They were very close; the housekeeper had worked for him for more than ten years. One day in December this relationship was put on the test when the mother of the housekeeper died unexpectedly of malaria. The housekeeper turned to Mr. Mashanga, his patron or bwana, for support. The housekeeper told me that he simply had no one else who could help him since he and his family were poor and the home village far away. He was the only one of his family who was employed in town, his relatives were subsistence farmers and they expected him to arrange the transport of his mother and the funeral in the home village. In turn, he expected Mr. Mashanga would help him because he was 
his patron whom he had always served loyally and who generally was considered to be a good man looking after his dependants.

Mr. Mashanga really wanted to help his housekeeper who was obviously very upset. When I asked for his motivation he responded that his housekeeper was like a relative to him and that he had served him well. Thus he felt obliged to help him. Yet, he faced several difficulties in helping the housekeeper. First of ail, there was no transport available. His own car had been grounded for a couple of months. It had a motor problem and the necessary spare part was not available in Malawi and anyway, he could not afford a replacement at the moment since the spare part would cost him at least two months salary. Prices for spare parts had rocketed in the past months due to the high inflation rate of more than $30 \%$. But even if his car would have been operational it would not have been really suitable for the transport of a corpse and the family members attending the funeral in the home village. When I suggested that he could rent a pick-up he said that that was not possible because it would be far too expensive. He would try to arrange for vehicles from the office. That was the easiest and cheapest option as he assured me.

But it also seemed to be a somewhat illegal option, too. According to the Malawi Public Service Regulations (MPSR) (Supplement $1: 192.1,192.2)$ the government provides a coffin and vehicles to transport the body and the guests to the place of burial only for the civil servant him- or herself or a civil servant's family member living at the service station. Despite their apparent rigidity even official regulations leave some leeway since it is not defined who exactly qualifies as a family member living at the service station. In a typical civil servant's household, where distant relatives often stay for weeks or months, this border is often difficult to draw. Stretching the meaning and with a little bit of goodwill even a nephew or cousin on a visit could be considered to be a 'family member living at the service station' as long as there was some kin relation and the relative died at the service station. In Mr. Mashanga' s case the situation was a little bit more complicated. Although his housekeeper had worked for him a long time and was considered by Mr. Mashanga to be a relative, abwale, he would not qualify as a member of family in terms of the Malawi Public Service Regulations (MPSR), which do not recognise fictive kinship.

During an earlier meeting he had told me that "everything concerning the civil service is in there [i.e. the MPSR]" but when I asked him whether it was against the rules to get the government vehicles for the funeral of his housekeeper's mother he replied that the official regulations "existed only on paper", the real problem was whether the vehicle would be available or away on other, more urgent, business. And indeed, I later heard that he had arranged not only one but two cars with drivers within a day. After the funeral in the village the drivers had stayed overnight in a trading centre nearby since it was already too late to return to town. Probably they even received a subsistence allowance for this overnight stay. This would mean that the trip had been classified as official duty and that the drivers had received a reward since allowances usually exceed real costs. It would also mean that Mr. Mashanga was able to avoid to pay the drivers for their services himself. By using government resources he utilised the possibility to minimise costs for himself. In the end he only had to pay condolence money which was about $10 \%$ of his monthly salary, still a considerable sum of money. This money was used by his housekeeper to cover the other costs of the funeral such as food and drinks for the guests. 

disregard. On the contrary, all involved followed official procedures; Mr. Mashanga submitted a request for the vehicles, the superior officer who signed the transport order, the executive officer who countersigned it and the drivers who filled in their logbooks. This seems to imply a contradiction since the rules were not applied in regard to the question whether he was entitled to use the cars. At that point another set of rules outside the realm of the office was invoked, i.e. Mr. Mashanga's obligations towards his housekeeper. At the office everybody fully understood that he had to fulfil his social obligations and the impossibility to refuse the request by referring to official regulations. As patron the employer has a responsibility not only for the employees but also for family members. A civil servant who would deny access to the state's resources would appear selfish and heartless, ubombo. Although employers often complain about this often quite costly obligation, it is virtually impossible for them to reject such a request on their resources since funerals have the highest priority in social life and anybody who appears to have no empathy in such a matter would be threatened by ostracism and witchcraft. Mr. Mashanga' s case illustrates that assistance with a funeral, kutandiza ndimaliro, may constitute an act of katangale, conduct that may be silently tolerated yet publicly condemned. Because of the ambiguity of the concept of katangale. Mr. Mashanga's actions were considered to be unselfish and the right thing to do and were strongly approved by colleagues and outsiders alike. Katangale is part of the game and often a necessary circumvention of rigid bureaucratic rules that are not applicable in the real world, which is characterised by insecurity and unpredictability. Therefore, the expected redistribution or sharing, kugawa/kugawira justified the transgression of official rules in Mr. Mashanga's case. former are highly flexible, open for negotiation and determined by the relationships the people have with each other, while the latter are strict and abstract. This conflict between two contradicting obligations has to be balanced by a third set of rules; the pulling of strings at the office is subject to the rules and principles of the unofficial code of conduct, which exists parallel to official regulations. Brokerage on behalf of his client had consequences for the social networks at the office : he became indebted to his superior officer, the driver and in a more indirect way to his colleagues at the department who know about the improper use of the vehicle. His ability to arrange two cars within a day for a trip far away gives testimony to his high status and influential position within the department. Furthermore, considering the ease with which he was able to arrange not only one but two cars with drivers indicates also that there might have existed a debt on the part of his superior officer and other colleagues stemming from earlier acts of katangale committed by them. Another factor for the ease with which he could arrange the cars was a legitimate reason : everybody understood that a funeral is too important to be avoided by referring to the official regulations "that only exist on paper" anyway.

Still, Mr. Mashanga had to take special care of the interfaces between the official and the parallel networks. That is the reason why he needed to get the consent of his superior officer, for example.

The relative ease with which Mr. Mashanga was able to circumvent the restrictions of the civil service regulations does not imply that the official regulations are irrelevant. On the contrary, they are applied - albeit in a selective manner. If you have the

Bulletin de l'APAD, 23-24 | 2002 
necessary contacts and relationships of indebtedness with others you can use the unofficial code of conduct as a resource to get your way and official rules blocking the way melt like snow in the sun. But in the unfortunate case that you have no contacts or debts official rules you have never heard of before will be applied to the very letter. of course someone who has achieved Mr. Mashanga's position has to have contacts and knowledge to play the game between official and parallel unofficial rules, otherwise he would not have his present position in the first place. Therefore one often hears about the absurd situation that someone who is in principle entitled to a service but has no contacts in the office is driven to despair by the required forms, stamps, signatures and counter-signatures while someone who has the influence but is actually not eligible gets the same with the wink of an eye.

Three sets of rules intertwined - the official rules, kinship rules and the unofficial code of conduct

The central question that arises from Mr. Mashanga's story is whether his actions were corrupt or not. We could argue that they were corrupt since he violated official regulations. On the other hand, it is clear that the people involved considered his actions to be morally right. Therefore we can understand his story as an example of the chameleon's careful manoeuvring between conflicting normative orders, thereby drawing on different norms as resources. Simplifying considerably for the sake of clarity I distinguish three different normative orders. Firstly, the official rules and regulations regarding corruption, conduct and discipline. Secondly, the principles and rules of social relationships, primarily kinship and fictive kinship. And thirdly, the internal unofficial rules within the civil service, i.e. the rules of the bureaucratic semi-autonomous social field. These rules are different from official regulations which are made by the government and the Human Resources Department, they have evolved from daily practice and often mediate between official rules and external rules of kinship relationships.

Official norms - the Malawi Public Service Regulations, statutes and circulars

To get a better grip on the unofficial rules of the modus operandi within the civil service one should consider legislation, official regulations and circulars issued by the Secretary of the President and the Cabinet and the Secretary of Human Resources to be external rules rather than internal rules since they are generated outside the bureaucracy by a small group of cabinet ministers and top official of the Office of the President and the Cabinet and perceived to "exist only in the book" by the rank and file. ${ }^{11}$ In recent years state law has been incorporating a growing body of institutions and rules originating in the transnational realm of World Bank and IMF policies on "good governance" and "combat against corruption" thus adding an extra layer to legal pluralism within the civil service of Malawi.

A senior officer described the Malawi Public Service Regulations (MPSR) as "the bible of the civil service". This body of rules is supposed to regulate exhaustively the conditions of service. There have been only two editions, in 1978 and 1991. Since then the provisions have been altered, updated and supplemented by a vast number of circulars, which are usually issued by the Secretary of the President and the Cabinet and the Secretary of the Human Resource Department. Despite all these amendments the rules, the terms of service and the structure of the civil service have basically remained the same since British colonial rule. ${ }^{12}$ Specifically in regard to corruption the following institutions and statutes are relevant. Since colonial times the Auditor General's Office 
has been the primary department controlling the ministries accounts. This institution has been joined by the Anti-Corruption Bureau (ACB), the Department of the Public

Prosecutor and the Public Accounts Committee of Parliament in the late 1990s. The central legal provisions can be found in the Penal Code and the Corrupt Practices Act of 1995, The latter is the product of the implementation of World Bank and IMF policies on 'good governance' and anti-corruption.

Thus, state law and institutions are not a homogenous system but in itself a rather heterogeneous mix with different genealogies determined by changing geopolitical constellations : firstly, from independence in 1964 till democratisation in 1993/1994 under Kamuzu Banda's authoritarian regime the highly centralised and hierarchical structure of the colonial public service was retained and even strengthened and, secondly, since 1994 there have been feeble attempts to transform the service into a "right-sized", "decentralised", "performance-driven", "transparent", "accountable" and "efficient" provider of public services controlled by democratic institutions and the general public under guidance of the World Bank, the IMF and bilateral donors, As a result of these demands the government is in the process of implementing a privatisation programme, a civil service reform programme and a decentralisation programme. ${ }^{13}$ In Malawi the World Bank adopted the so-called 'enclave approach' to governance reform. Hereby new agencies are established that are supposed to function as motors of reform (Dia 1993), Instead these reforms have not been very successful in transforming the civil service and reforms co-exist uneasily with structures dating back to the colonial period. This situation has resulted in a pluralism of state agencies and legislation. ${ }^{14}$

Despite the shifts in emphasis basic assumptions about the nature of the civil service remain unchanged : the division of the public office from private life, the prohibition of using public resources for private gains, the impartial implementation of public policies and depersonalised professional relationships ${ }^{15}$ Accordingly, the MPSR contain a chapter on conduct and discipline ${ }^{16}$ sanctioning for example the use of information for personal gain, the use of public monies or property for private purposes, activities which conflict with the interests of the government or be inconsistent with a civil servant's official duties, etc. The MPSR are supplemented by the Corrupt Practices Act (1995), prohibiting bribery and extortion, and the Penal code, which covers theft and fraud by civil servants. In addition, numerous circulars of the Secretary of Human Resource Management address specific problems such as misuse of government vehicles.

In spite of the scope of official rules and legislation in reality the risk of discovery and punishment for corrupt civil servants is very low. Of course the President and the ministers are eager to point out that corruption is an evil and that no one stands above the law. And indeed in recent years several high-profile scandals involving ministers and high officials have led to temporary arrests, transfers and suspensions, But not only grand corruption has been tackled by ACB and the Public Prosecutor, occasionally "small fish" such as customs officers and clerks are persecuted and sentenced to severe punishment if convicted. However, control by these institutions and the notoriously understaffed Auditor General's Office is incidental at best and enforcement of the various statutes and official regulations seems to be not universal but rather restricted to a few isolated cases that are supposed to have a deterrent effect or serve political purposes of political rivals. Furthermore, the rivalry and unclear mandates of these 
institutions has counter-productive effects: instead of enhancing anti-corruption measures it seems rather to have a paralysing effect. With regard to the effect of sanctions it is difficult to assume a simple direct causal link between non-compliance and shortcomings in law-enforcement. In any case, failing enforcement is certainly not conducive to law-abiding behaviour by civil servants in a bureaucracy where self-enrichment and abuse of public property seem to be rather the norm than the exception.

Social networks - norms and ideology

Despite "modernisation" and urbanisation, in most parts of Sub-Saharan Africa social networks are vital in regard to people's identity and their social security. A person's status is defined to a large degree by the number of personal relationships he or she entertains and how much of one's wealth is redistributed among kin and clients. Due to the absence of universal and substantial social welfare services people in general have to rely for their social security on their networks with kin, colleagues, neighbours, etc. Most writers have emphasised the role of informal or traditional networks with regard to the widespread corruption in Sub-Saharan Africa (Blundo \& Olivier de Sardan 2001a, Médard 1982:172; 1995 ; Olivier de Sardan 1999: 256, 257 ; Scott 1979: 43-45). Civil servants act as brokers and patrons within a web of interdependent social networks transcending the sphere of the public office. This position makes them receptive for the temptation of corruption. It is almost impossible to refuse the demands of a relative, a friend or an old schoolmate to assist, even if it means one has to circumvent official rules.

40 Generally in Malawi there is a strong moral obligation to redistribute, kugawa or kugawira, i.e. to share, accumulated wealth with kin. The generous patron enjoys considerable status among his clients. In turn, the connection with a powerful patron enhances the social status of a client.

41 The achievement of an individual is al ways seen as a collective achievement by a potentially wide circle of relatives, which will grow to the same extent as one moves upward the social ladder to the extent that the senior civil servant or the successful businessman will be visited by 'relatives' he didn't even know existed. It is considered to be an essential social obligation for kin to support each other and there is always the implicit threat of ostracism and witchcraft accusations if someone appears to be selfish or too individualist. Social control within these networks is usually tight and the implicit threat of witchcraft, ostracism and gossip functions as a sanction inducing conforming behaviour.

The strength of solidarity networks should not be confused with an idealised picture where all corrupt behaviour by public officials is a logical consequence of demands for support. Civil servants are active agents, brokers who continuously negotiate the terms of their social relationships making sure that they get their share of the cake. Often civil servants themselves point out that it is no wonder that other officers (of course it were always others) are corrupt when they are confronted by the obligations of extended families and the limitations of low salaries eroded by inflation. This is often not more than an excuse for corrupt behaviour; not everybody is the same : some were not corrupt, others were manipulating and circumventing official rules under severe circumstances only like $\mathrm{Mr}$ and some were downright corrupt without the pretext of social obligations and solidarity, using the gains from corruption for hedonism and escapism. The numerous civil servants who can be encountered in the bars and of the 
urban and peri-urban areas where they spend a month's salary in one night give ample testimony of this selfish and anti-social aspect of corruption.

Civil servants maintain diverse social relationships with neighbours, colleagues, old schoolmates and fellow members of the church congregation. In an urban and modern environment other networks based on residence, social status and church membership are very important. Often the se relationships are described in terms of fictive kinship, especially in regard to solidarity. Yet one should be careful to lump all social relationships and personal exchanges under one header as many authors seem to suggest (Ekeh 1975; Médard 1982; Olivier de Sardan 1999; Scott 1979). Civil servants themselves often made a distinction between kin and friends. Of course, relationships with neighbours, colleagues and people from the same congregation can be under strain from demands for support but most civil servants 1 met stressed the pressure from relatives who expect them to provide support as a major issue of their existence. With regard to friends my informants often stressed that a friend could put less stronger claims on their resources. In spite of these complaints their attitude towards expectations by kin is often ambiguous : on the one hand, exaggerated expectations are perceived to be a burden in an environment characterised by severe economic crisis and loss of real income; on the other hand, the status that comes with the role of a broker and patron is very tempting and kin relations are seen as insurance, a potential asset which has become increasingly important in recent years under impact of the economic crisis.

When we talk about the rules regulating informal social support it is difficult to represent them as a normative system of defined rights and obligations. It is rather a cluster of basic principles, which order the sphere of personal relationships. Instead of speaking of rights and duties it seems more appropriate to talk about expectations and feelings of obligation embedded in social relationships. The feeling of obligation is generally very strong, it is virtually impossible to reject a demand for support, especially from kin, and people devise the most complicated schemes to avoid or at least to control the demands from their relatives. Exchanges are often never fully consumed to maintain a sense of indebtedness, which leaves open the possibility to ask for favours or services at a later point of time. Parallel, terms and conditions of exchanges tend to be implicit and vague, thus leaving space for changes in interpretation and a continuous process of negotiation.

For example, the responsibility of the employer is not limited to his employee. As employer Mr. Mashanga is expected to support his employees and their families in times of distress. The employer is generally expected to arrange for or to pay the funeral and costs of transport of the deceased's body to the place of the funeral, usually the home village. There is no clear rule since it is neither in the interest of the employer and the employee to define more precisely who would benefit from the employer's support. Thus both parties have the possibility to negotiate the conditions of help in the light of the specific circumstances of the situation. A more precise definition would be considered undesirable by both parties: the employer wants to avoid to give the impression that he or she is keen to limit his obligations and it is obviously in the employee's interest to have as little as possible restrictions on support from the bwana.

This brief sketch of principles ordering social relationships in Malawi seems to correspond with Ekeh's concept of the "primordial public realm" as opposed to the 
"civic public" associated with colonial rule, which is devoid of moral imperatives ${ }^{17}$. He seems to suggest that a homogenous set of moral imperatives operates in the "primordial public" and influences the private sphere. In my view, this conceptualisation is misleading: in general the idea of a primordial realm is anachronistic at best and seems to be inspired by a search for authenticity rather than social realities in modern Africa. In present-day Malawi there exists not one universal morality but rather a patchwork of different moralities. Often the differences are negligible, as for example between different ethnic groups who have similar moral imperatives, but sometimes they are considerable. This is certainly the case in regard to Christian morality and kinship morality, which are often at odds and give rise to tension and conflict. Ekeh asserts that "Christian beliefs have provided a common moral foundation for the private and the public realms in Western society" (1975 : 92). His concept of the "primordial public" in Africa, which he primarily associates with kinship and ethnicity, ignores the profound influence Christian missionary activities and social change have had on African societies. ${ }^{18}$

Often civil servants who are devout Christians, especially the rising number of "born-again" or "charismatic" Christians, have high moral standards in regard to an individual's personal conduct. Christian ethics differ in important aspects from kinship-influenced moral imperatives : Charity is a moral duty for Christians but unlike solidarity between kin with strong social pressure applied by members of the group the obligation is based on the belief in god and a hereafter where good deeds will be rewarded or bad deeds will be punished. Corruption or katangale constitute sinful behaviour and for some charismatic churches the devil himself tries to seduce the believers from the path of god by tempting them to act wrongly. This strong rejection of illegal acts, which can be traced back to the acknowledgement of secular power in all Christian churches ${ }^{19}$, differs from kinship solidarity, which does not recognise the distinction between public office and private sphere. Hence, it is more appropriate to replace the notion of a "primordial public" by conceptualising a mix of alternative moralities which might have conflicting elements. It is possible that the rise of the new charismatic churches will have a more profound effect on ethics in the civil service than all official programmes for "good governance" together.

Unofficial rules within the civil service

In this paragraph I want to turn to the third set of rules relevant for assessing corrupt behaviour in perspective. Beneath the layer of statutes, regulations and bureaucratic hierarchies there is a complex web of interpersonal relationships amounting to a parallel structure within the civil service running mainly along the lines of patron-client and peer relationships with its own rules in regard to corruption ${ }^{20}$. These informal relationships are regulated by a set of generally accepted rules, which are different from the official rules and regulations. They are very vague, open to negotiation and not available to outsiders. This observation holds to some extent for all bureaucracies throughout the world. In my point of view bureaucracy in Malawi is different in two aspects. Firstly, official rules are often extremely far removed from the actual situation on the office-floor that the emergence of an informal set of internal rules that amend or shortcut official procedures is almost inevitable since official procedures simply do not work in complicated everyday life. Secondly, informal networks generally tend to be stronger and more extended and the ability of the state to implement public policies and to enforce the rule of law is weaker than in the West. 

which gives raise to the informal modus vivendi with its own rules. Civil servants have to come to terms with official rules and procedures, patron-client relationships at the office, their obligations towards kith and kin and influence from interest groups and political parties. In this paper official rules and regulations as the MPSR are conceptualised as external and the informal rules in the bureaucracy as internal. of course, the official regulations are internal in the sense that they only apply to the civil service but civil servants themselves do perceive them as external since they originate in the cabinet and the top of the civil service. In contrast, the clandestine rules, which have the tendency to undermine official rules, emerge from the social field of the bureaucracy itself. rules. Many civil servants I have talked to emphasised the choking atmosphere of distrust, social control and strength of the unofficial code of conduct in the government's offices. Young and idealistic officers often bemoaned the culture of corruption and low motivation in the bureaucracy. Yet, it was unthinkable for them to resist social control from colleagues and superiors. Open disagreement with superiors is a violation of the office mores which is usually described in terms of 'respect to the master', ulemu kwa bwana. Resistance or rebellion would le ad to social isolation, considerable diminished career opportunities and restricted access to attractive posts and workshops.

51 Social relations within the bureaucracy have two central features : asymmetric power relations and the maintenance of indebtedness. Junior civil servants usually draw a sharp line between 'the bosses' and themselves who depend on protection by their superior officers. Without the intervention of a patron or friend it is almost impossible to get a salary advance, the permission to attend a workshop, to be promoted or even to get a job in the first place. For example, in many government departments it is understood that you have to paya "commission" to your superior officer if you want to get a salary advance. Indebtedness is the other important aspect of relationships inside the civil service. Mr. Mashanga's story shows how personal relationships at the office produce and reproduce indebtedness and katangale. The production and maintenance of indebtedness is desirable for both parties, the debtor and the creditor. The interest of the creditor is obvious : he or she gains influence over the debtor. Often full return is not in the interest of the creditor who might want to maintain his position of power. But even the debtor will often perceive of a debt as an as set. If it is not possible to become a creditor the next best thing is the status of a debtor. To have a debt is a means to establish a social relationship with someone who might feel obliged towards the weaker party.

Obviously there exist differences between different departments and sub-units like offices and schools. Firstly, the attitude towards corruption of the officers heading a sub-unit usually sets the tone for the rest of the staff.

53 This can be observed in Malawi generally where corruption has spread from the top to the bottom since the early 1990s. One can speak of a democratisation of appropriation that has been taking place since the introduction of multi-part democracy in 1994. Secondly, the functions of the Fisheries Department, for example, are different from those of a primary school. Nevertheless there is a set of basic informal rules and codes, which can be found to some extent in all ministries and departments down to the

Bulletin de l'APAD, 23-24 | 2002 
smaller units of police posts, health posts and schools. Civil servants often allude euphemistically to these rules as "know how to manœuvre" or the "rules of the game". The most important principle is "respecting the boss", kulemekeza or ulemu kwa bwana. Another important principle is kugawa/kugawira mentioned above. One of the obligations of the bwana, the boss or master, is to ensure that his or her subordinates receive their share. The boss who violates this principle might face some kind of silent resistance or revenge, for example in the form of corruption allegations. Junior officers tend to tolerate or even condone corruption by the superior officers as long as it is katangale, a system of redistribution in which everybody involved benefits. This attitude of junior civil servants is nicely illustrated in the song Ndiphike Nyemba by Charles Nsaku that was very popular in early 2002. A driver accuses his boss of being selfish, "I am your driver, we left Lilongwe together the previous day coming here to the field to work, there you are with money boss, food you are just eating alone, while your driver ate two days ago". These accusations of being selfish or ubombo are not something to be lightly taken in a society where the obligation to share is a central principle of conduct. In the song Njoka $m u \mathfrak{u d z u}$ by Lucius Banda the junior officer compares his boss to a snake lacking basic human qualities: "You are like a snake in the grass, when passing us by you smile, deep down in your heart you harbour bad feelings towards us, what is that you are missing boss?" He also warns his boss that one day he might have to depend on his subordinates since "life is like a card game, today we are working for you but your children might be employed by us".

Conclusions

Corruption is a normative concept rooted in the Weberian distinction between the public office and the private sphere and is just one of several sets of rules co-existing in the Malawian bureaucracy. The official rules suffer from a lack of legitimacy, they are experienced to be too far removed from the realities inside and outside the office. This lack of recognition is not limited to lower level bureaucrats but also widespread among superior officers, especially since democratisation in 1994 which has been a period of profound changes in Malawian society. Moreover, enforcement of rules is hampered by unclear mandates and lacking resources of controlling organisations such as the ACB, often locked in competition against each other.

Mr. Mashanga' s story illustrates the unpredictability and insecurity in civil servants' daily lives that often put them in difficult situations where violation of official rules is the lesser evil. Obligations against kin and clients are felt very strongly and it is not easy to resist taking advantage of the weak enforcement of the official rules. The social pressure on civil servants is high since kinship ideology does not acknowledge the separation of the public and the private sphere. Consequently, the idea of a misuse of the public office for private ends has no place in kinship morality and it is difficult to justify a refusal to assist by referring to official rules. Compliance to the social obligations is motivated by the high degree of social control such as the threat of witchcraft, ufiti, and social isolation. Moreover, everybody, even the privileged, has to take his or her own dependence on assistance by others into account.

However, two qualifications de serve emphasis. Firstly, one should not assume the existence of one homogenous 'primordial realm' based on a authentic African identity opposed to the foreign colonial public realm of the state institutions which lack legitimacy. In fact, kinship is just one of man y alternative public realms with different concepts about good conduct, which might even be mutually exclusive such as kinship 
morality and charismatic Christian belief, for example. Secondly, civil servants are active agents exploiting ambiguities and gaps resulting from legal pluralism. Even the lowest civil servants occupy a relatively privileged position. This makes them important brokers in their social networks and constantly people try to make claims on them by reminding them of their social obligations. Thus, civil servants experience a tension between official rules and their everyday lives. Neither can be ignored but the tension is reduced to an acceptable level by the creation of a body of unofficial office rules. Primarily, this modus vivendi provides a matrix for the application of official rules. Mr. Mashanga's case illustrates this virtuous playing with different sets of rules to maintain one' s position both, in the office and the "private" sphere.

An analysis that takes indigenous concepts such as katangale and kugawa into account transcends the simple public/private, legal/illegal dichotomies abounding in non-anthropological treatments of the phenomenon. The recognition of legal pluralism in the bureaucracy of Malawi reveals alternative dichotomies such as selfish/altruistic and different ideas of conformity and deviance that make it more difficult to believe in the potential of universalistic concepts such as the rule of law and good governance for curbing corruption. We would be better advised to have a closer look at the alternative sets of rules and moral ideologies for guidance in approaching a phenomenon that is neither inherent to African society nor the symptom of a mere dysfunctionality of an inefficient bureaucratic machine.

\section{BIBLIOGRAPHY}

Anders G., 2002a, "Freedom and Insecurity : Civil Servants between Support Networks, the Free Market and the Civil Service Reform." In : Englund, Harri (ed.) A Democracy of Chameleons : Politics and Culture in the New Malawi. Uppsala/Somerset : Nordic Africa Institute/Transaction Publishers : 43-61.

Anders G., 2002b, The "Trickle-down" Effects of the Civil Service Reform in Malawi - Studying Up. Paper presented at the International Conference on "Legal Pluralism and Unofficial Law in Social, Economic and Political Development" of the Commission on Folk Law and Legal Pluralism, Chiang Mai, Thailand, vol. 7, n 10, 2002.

Bayart J.-F., 1993, The State in Africa. The Politics of the Belly. London/New York : Longman.

Von Benda-Beckmann K., Strijbosch F., (eds.) 1986, Anthropology of Law in The Netherlands. Essays in Legal Pluralism. Dordrecht : Foris.

Blundo G., Olivier de Sardan J.-P., 2001a, "La corruption quotidienne en Afrique de l'Ouest." Politique Africaine $\mathrm{n}^{\circ} 83$ : 8-37.

Blundo G., Olivier de Sardan J.-P., 2001b, "Sémiologie populaire de la corruption." Politique Africaine $\mathrm{n}^{\circ} 83$ : 98-1 14 .

Boissevain J., 1974, Friends of Friends. Networks, Manipulators and Coalitions. Oxford : Blackwell. 
Chabal P., Daloz J.-P., 1999, Africa works : Disorder as a Political Instrument. Oxford/Bloomington \& Indianapolis : James Currey.

Comaroff Jean and John, 1991-1997, On Revelation and Revolution. vol. 1 \& 2. Chicago : Chicago University Press.

Dia M., 1993, A Governance Approach to Civil Service Reform in sub-Saharan Africa. Washington D.C. : The World Bank.

Dzimbiri L.B., 1998, "Democratic Politics and Chameleon-like Leaders." In : Phiri, Kings M./Ross, Kenneth R. (eds.) Democratization in Malawi : A Stocktaking. Blantyre/Bonn : CLAIM/Verlag für Kultur und Wissenschaft.

Ekeh P., 1975, "Colonialism and the two publics in Africa : a theoretical statement." Comparative Studies in Society and History, $\mathrm{n}^{\circ} 17: 92$.

Ehrlich E., 1967/1913, Grundlegung der Soziologie des Rechts. $3^{\text {rd }}$ ed. Berlin : Duncker \& Humblot.

Englund H., 2002, "Introduction : The Culture of Chameleon Politics." In : Englund, Harri (ed.) A Democracy of Chameleons : Politics and Culture in the New Malawi. Uppsala/Somerset : Nordic Africa Institute/Transaction Publishers : 11 -24.

Epko M.U., 1979, "Introduction." In : ibid. (ed.) Bureaucratic Corruption in Sub-Saharan Africa : Toward a Search for Causes and Consequences. Washington D.C. : University Press of America : 1-9.

Galanter M., 1981, "Justice in many rooms." Journal of Legal Pluralism, vol. 19 : 1-47.

Gardiner J., 2002, "Defining Corruption." In : Heidenheimer, Arnold J. \& Johnston, Michael (eds.) Political Corruption. Concepts and Contexts $3^{\text {rd }}$ ed. New Brunswick/London : Transaction Publishers : 25-40.

Harsch E., 1999, "Corruption and State Reform in Africa : Perspectives from Above and Below." In : Wohlmuth, Karl/Bass, Hans H. \& Messner, Frank (eds.) Good Governance and Economic Development. Muenster : LIT Verlag : 65-87.

Heidenheimer A. J., Johnston M., 2002, (eds.) Political Corruption : Concepts and Contexts. $3^{\text {rd }}$ ed. New Brunswick/London : Transaction Publishers.

Hyden G. 1980, Beyond Ujamaa in Tanzania : Underdevelopment and Uncaptured Peasantry. London : Heinemann Educational.

Kaspin D., 1995, "The Politics of Ethnicity in Malawi's Democratic Transition." Journal of Modern African Studies, vol. 33, $\mathrm{n}^{\circ} 4: 595-620$.

Klitgaard R., 1988, Controlling Corruption. Berkeley : University of California Press.

Malawi Government, 1978, 1991, Malawi Public Service Regulations. Lilongwe : Government Printer.

Mapanje J. 1981, Of Chameleons and Gods. Oxford : Heinemann.

McCracken J., 2000/1977, Politics \& Christianity in Malawi 1875-1940. Blantyre : CLAIM.

Médard J.-F., 1982, "The Underdeveloped State in Tropical Africa : Political Clientelism or Neo-Patrimonialism ?". In : Clapham, Cristopher (ed.) Private Patronage and Public Power : Political Clientelism in the Modern State. London : Frances Pinter : 162-192.

Médard J.-F., 1995, "La corruption politique et administrative et les différenciations du public et du privé : une perspective comparative." ln : Borghi, M. \& Meyer-Bisch, P. (eds.) La corruption : l'envers des droits de l'homme. Fribourg : Editions Universitaires. 
Merry S.E. 1988, "Legal Pluralism." Law and Society Review, vol. 22, nº 5 : 867-896.

Moore S.F., 1973, "Law and Social Change : The Semi-Autonomous Social Field as an Appropriate Subject of Study." Law and Society, Review : 719-746.

Moore S.F., 2000/1978, Law as Process. An Anthropological Approach. Hamburg/Oxford : LIT Verlag/ James Currey.

Mooij J., 1992, "Private Pockets and Public Policies : Rethinking the Concept of Corruption." In : von Benda-Beckmann, Franz \& van der Velde, Menno (ed.) Law as a Resource in Agrarian Struggles. Wageningen Sociologische Studies 33 : Agricultural University Wageningen.

Olivier de Sardan J.-P., 1999, "African corruption in the context of globalization." In : Fardon, Richard/van Binsbergen, Wim \& van Dijk, Rijk (eds.) Modernity on a Shoestring. Dimensions of Globalization, Consumption and Development in Africa and Beyond. Leiden/London : EIDOS/ASC/CASL : 247-268.

Schofeleers M., Roscoe A., 1985, Land of Fire : Oral Literature from Malawi. Limbe (Malawi) : Popular Publications.

Scott J.C., 1979, "The Analysis of Corruption in Developing Nations." In : Epko, Monday U. (ed.) Bureaucratic Corruption in Sub-Saharan Africa: Toward a Search for Causes and Consequences. Washington D. C. : University Press of America : 29-61.

Skinner T.M., 1963, Report of the Nyasaland Local Civil Service Commission of Inquiry. Q 814. Zomba : National Archives of Malawi.

Snyder F., 1993, Law and Anthropology : a Review. EUI Working Paper LA W n 93/4. Florence : European University Institute de Sousa Santos B., 1995, Toward a New Common Sense : Law, Social Science and Politics in the Paradigmatic Transition. London/New York : Routledge.

Tilman R.O., 1970, "Black-Market Bureaucracy." In : Heidenheimer, Arnold J. (ed.) Political Corruption. Readings in comparative analysis. New York : Holt/Rinehart/Winston.

Vail Leroy, White Landeg 1991, "Tribalism in the Political History of Malawi." In : Vail, Leroy (ed.) The Creation of Tribalism in Southern Africa. Berkeley/Los Angeles : University of California Press : 151-192.

Wade R., 1984, "The system of administrative and political corruption : canal irrigation in India." Journal of Development Studies, vol. XVIII, n³ : 287-328.

Weber M., 1990/1921, Wirtschaft und Gesellschaft : Grundriss der verstehenden Soziologie. $\mathrm{n}^{\circ}$ 5, ed. Tübingen : Mohr.

Wertheim W.F., 1964, East-West Parallels. Sociological Approaches to modern Asia. Den Haag.

Woodman G.R., 1998, "Ideological Combat and Social Observation : Recent Debate about Legal Pluralism". Journal of Legal Pluralism, $\mathrm{n}^{\circ} 42: 21-59$.

World Bank, 1994, Malawi Public Service Pay and Employment Study.

World Bank Southern Africa Department. Report n 13071-MAI.

World Bank, 2000a, Helping Countries Combat Corruption : Progress at the World Bank since 1997. Washington D. C. : The World Bank.

World Bank, 2000b, Reforming Public Institutions and Strengthening Governance. Washington D.C. : The World Bank. 


\section{NOTES}

1.Moore $(2000 / 1978): 1$.

2.Boss - it pleases you to see us reading newspapers and playing bawo [East-African board game] during lunch hour while you spend your time with hookers, enjoying and eating at Ryall's [expensive hotel in Blantyre].

3.The image of the chameleon is very strong and rich resonating with stories and myths. The chameleon is a morally ambiguous character in tales and myths from Malawi's past (Schoffeleers \& Roscoe $1985: 17-38$ ). In postcolonial Malawian poetry the image of the chameleon was used as a metaphor to depict survival strategies under the authoritarian regime of Kamuzu Banda between the early 1960s and 1994 (Mapanje 1981). Lately the image has been used to describe politics and politicians since democratisation in 1994 (Dzimbiri 1998, Englund 2002).

4.I adopt Boissevain's definition of a broker. See Boissevain (1974:147).

5.For example, Tilman (1970) and Klitgaard (1988) adopt an economic point of view whereas Scott (1979) and Médard (1982) have a more political perspective on corruption. For a recent quite exhaustive overview of various economic and political science approaches see Heidenheimer \& Johnston (2002).

6.And indeed salaries are generally quite low : the Most junior grades like security guards, gardeners and messengers earn about US $\$ 20$ per month. Extension workers and primary school teachers earn between US $\$ 25$ and US $\$ 30$ per month. Even officers with higher qualifications, like a diploma or a bachelor's degree, rarely earn more than US $\$ 50$ per month : junior professional officers as secondary school teachers, for example. have a monthly salary of $\$ 40$. The highest grades, in the Superscale, earn roughly US $\$ 100$ per month.

7.Excluding European and US consultants hired by the World Bank who earn several hundred US \$ a day.

8.The analysis of everyday language has been identified as a useful tool in anthropological research of corruption. See e.g. Blundo \& Olivier de Sardan (2001b) on the "popular semiology of corruption" in francophone West-Africa.

9.For overviews on legal pluralism see e.g. von Benda-Beckmann \& Strijbosch (1986) ; Merry (1988) ; Snyder (1993); Woodman (1998).

10.On the history of the promotion of Chewa-identity under Banda see Vail \& White (1991) and Kaspin (1995 : 602-611).

11.On the differentiation between external rules and internal rules see Moore (2000/1978.1973). This can be also conceptualised as the difference between "Iaw in the books" and "Iaw in action" according to one of the founding fathers of legal anthropology ; see Ehrlich (1967/1913).

12.Skinner (1963). See also World Bank (1994).

13.For an anthropological study of the implementation of the civil service reform see Anders (2002b).

14.De Sousa Santos refers to this fragmentation of the state as internal legal pluralism or interlegality (1995: 281).

15.See the blueprint of bureaucratic authority by Max Weber (1990/1921) : 551- 579 . 16. Malawi Government (1978/1991) Malawi Public Service Regulation : Book One, chapter Il.

17.Ekeh points out that there exist two public realms in the postcolonial state; firstly. the "primordial public" realm associated with traditional kinship relationships which is 
"moral and operates on the same moral imperatives as the private realm" and secondly. the "civic public" of the state's institutions based on the ideology of the colonial administration. which is "amoral and lacks the generalised moral imperatives operative in the private realm and in the primordial public" $(1975 ; 92)$.

18.On the encounter between Christian missionaries and Africans which amounted to more than mere colonisation since Africans also appropriated Christianity see e.g. Jean and John Comaroff (1991/1997). For Malawi see McCracken (2000/1977).

19. Of course there are differences between the various Christian churches. Protestant churches have a more pronounced tradition of being apolitical and recognising secular power than the Catholic Church. Yet. most churches recognise secular laws and adhere to the private/public distinction.

20.With an illustrative and evocative image Bayart refers to this characteristic of the postcolonial state in Africa as rhizome thus emphasising the subterranean and informal character of these parallel social and political networks which have penetrated the rational bureaucratic machine $(1993 ; 260-272)$.

\section{AUTHOR}

\section{GERHARD ANDERS}

Erasmus University Rotterdam, Faculty of law, international Law Legal Anthropology. 